\title{
A New Application For Flotation Of Oxidized Copper Ore
}

\author{
Recep Ziyadanogullari, Firat Aydin* \\ Dicle University, Faculty of Science and Art, Chemistry Department, \\ 21280, Diyarbakır-TURKEY
}

\begin{abstract}
:
In this study, the flotation of oxidized copper ore obtained from Ergani Copper Mining Company in Turkey was performed. This ore contains 2.03\% copper, 0.15\% cobalt and 3.73\% sulfur. An effective processing method has not been found to recover copper and cobalt from this ore, which has been stockpiled for 40-45 years in the idled plant. It was established that recovery of copper and cobalt from this ore with hydrometallurgical treatment is not economical, so using flotation to increase the concentration of copper and cobalt was chosen. When flotation of the oxidized copper ore was performed under standard operating conditions in the plant, good results were not obtained. Because of this, the flotation of samples obtained from sulfurized medium containing different ratios of $\mathrm{H}_{2} \mathrm{~S}+\mathrm{H}_{2} \mathrm{O}$ gases was done under the same conditions. Following flotation, it was seen that copper, cobalt and sulfur present in the medium were concentrated. In this solution, concentration of copper and cobalt were found five times higher than normal level.
\end{abstract}

Key Words: Oxidized copper ore, sulfurization, flotation, copper, cobalt, sulfur

\section{INTRODUCTION}

Many researchers have tried to recover copper and cobalt hydrometallurgically from the currently unusable ores of the Ergani Copper Mining Co. However, it has been reported that these operations were not economic, and removal efficiency was low $(3,11$, $17,18)$.

In addition to hydrometallurgical tests, flotation studies $(1,4-8,10,12-16)$ of the oxidized copper ore and different structures of copper ore have been carried out by many researchers using various flotation conditions.

Oxidized copper ores are found in many places in the world. Formation of this type of ore occurs in the same locations as other copper ores. Due to this, the economical evaluation of oxidized copper ore is important today. In another study, sulphidising flotation of oxide copper-cobalt ores, using sodium hydrosulphide as the sulphidising agent, has been practiced in Katanga, Democratic Republic of Congo. With sodium hydrosulphide, nearly $77 \%$ of the copper and $75 \%$ of the cobalt were recovered with a

*For correspondance : Fax: +90-412-2488039 Tel : +90-412-2488001/3159 E-mail: faydin@dicle.edu.tr 
concentration ratio of 3.0 . Using a $1 / 1$ combination of $\mathrm{NaHS}$ and $\left(\mathrm{NH}_{4}\right)_{2} \mathrm{~S}$, about $80 \%$ of the copper and cobalt have been recovered with a concentration ratio of 3.5 (9).

In this study, we attempted flotation of oxidized copper ore. When this was unsuccessful, we used a sulfurization process developed in our previous studies. As a result of this process a new surface forms on the oxidized copper particles and flotation experiments were carried out using these samples (2-3).

As was seen in the previous studies, successful results can not be obtained by direct flotation of the original oxidized ore. However, in this study, we obtained good results by flotation of a sample obtained from an appropriate sulfurization process.

\section{EXPERIMENTAL DESIGN}

\section{Material}

In this study, the oxidized copper ore used was supplied from the Ergani Copper Mining Co. Turkey. Ergani, which is in southeast Turkey, is a leading copper and pyrite ore production area.

Analyses show that the ore obtained from the Ergani Region contains $2.03 \%$ copper, $0.15 \%$ cobalt and $3.73 \%$ sulfur. Pyrite, chalcopyrite and oxidized copper ore are the main ore minerals present. In addition to this, carbonate, calcite, and clay minerals as gangue, and some important rare minerals are found in the orebody.

The K-Amil xanthate and Dowfroth 250 used in flotation were taken from the Ergani Copper Mining Co. in Turkey.

In our studies, $96 \%(\mathrm{w} / \mathrm{v}) \mathrm{H}_{2} \mathrm{SO}_{4}, 37 \%(\mathrm{w} / \mathrm{v}) \mathrm{HCl}, 65 \%(\mathrm{w} / \mathrm{v}) \mathrm{HNO}_{3}$ and $\mathrm{KClO}_{3}$ were purchased from Merck.

The experiments were conducted in a laboratory equipped with facilities for carrying out hydrometallurgical operations such as autoclave leaching. The composition of all solutions and samples were determined using a Unicam 929 Model AAS. Sulfur identification was also made by gravimetric methods.

Denver mark flotation apparatus, Heraus Model Furnace and Nel 890 Model pH meter were used for flotation, roasting and determination of $\mathrm{pH}$ of samples, respectively.

\section{Method}

The bulk sample was split into 100 gram fractions, ground to -100 mesh and dried at $110^{\circ} \mathrm{C}$. These samples were used in chemical analyses and flotation studies. $\mathrm{H}_{2} \mathrm{~S}$ was produced by addition of $\mathrm{H}_{2} \mathrm{SO}_{4}$ to $\mathrm{FeS}$ (2) obtained from pyrite. The sulfurization process was performed in an autoclave of 1.3 liter internal volume, with 60 minutes residence time. Different ratios of gas mixture of $\mathrm{H}_{2} \mathrm{~S}+\mathrm{H}_{2} \mathrm{O}$ were tested. 


\section{RESULTS AND DISCUSSION}

\section{The Flotation of Oxidized Copper Ore:}

This study was carried out under the conditions indicated in table 1. Flotation time was 3 minutes. In the first test with a run of mine ore sample, it was determined that the concentrate (copper and cobalt) obtained from this study was $5.07 \mathrm{~g}$ while the tailing was $92.53 \mathrm{~g}$. In untreated samples, $14.90 \%$ of the copper and $4.40 \%$ of the cobalt reported to the concentrate phase, which are not acceptable concentrations. In the second series of tests, oxidized copper ore was first sulfurized at $110^{\circ} \mathrm{C}$ by using various ratios of $\mathrm{H}_{2} \mathrm{~S}+$ $\mathrm{H}_{2} \mathrm{O}$. The sample after sulfurization was floated under the conditions stated above.

Table 1 : Flotation condition

\begin{tabular}{|l|l|}
\hline Particle dimension & -100 mesh \\
\hline Solid / Liquid Ratio & $100 \mathrm{~g} / \mathrm{L}$ \\
\hline Collector & $0.2 \mathrm{gZ}$ (KAX) 3 minute mix \\
\hline Frother & $0.5 \mathrm{ml}$ Dowfroth $250(1 \%) 2$ minute mix \\
\hline $\mathrm{pH}$ & 5.42 \\
\hline Mix rate & 900 periods / minute \\
\hline Flotation time & 3 minutes \\
\hline
\end{tabular}

\section{The Flotation of Samples with Sulfurization of Oxidized Copper Ore}

For the sulfurization process, two samples were prepared in two different autoclave mediums: Sample A containing $18.37 \mathrm{~g} \mathrm{H}_{2} \mathrm{~S}+120.00 \mathrm{~g} \mathrm{H}_{2} \mathrm{O}$ for one $\mathrm{kg}$ of copper ore, and Sample B containing $24.50 \mathrm{~g} \mathrm{H}_{2} \mathrm{~S}+160.00 \mathrm{~g} \mathrm{H}_{2} \mathrm{O}$ for one $\mathrm{kg}$ of ore. These samples were floated under the same conditions described previously.

The results presented in Table 2 and Table 3 show that the flotation efficiency varies considerably depending on $\mathrm{pH}$ of the medium and sulfurization of the oxidized copper ore.

Since the flotation efficiency increased more in sample B, additional flotation tests using sample $\mathrm{B}$ were performed using an activator $\left(\mathrm{CuSO}_{4}\right)$. This appeared to result in no difference in flotation efficiency. Therefore, the sulfurization process was applied to another one $\mathrm{kg}$ oxidized copper ore sample using the medium containing $30.63 \mathrm{~g} \mathrm{H}_{2} \mathrm{~S}+$ $200.00 \mathrm{~g} \mathrm{H}_{2} \mathrm{O}$ (Sample C). The flotation was done under the same conditions. Sulfur values from flotation of sample $\mathrm{C}$ shown in Table 4 and Figure 1 indicate that the flotation efficiency of $\mathrm{Cu}, \mathrm{Co}$ and $\mathrm{S}$ was $100 \%$ at the $\mathrm{pH}$ values of 8.7 and 8.8 . However, the flotation efficiency at $\mathrm{pH} 8.7$ was better than $\mathrm{pH}$ of 8.8 because of high percent values of these elements in the concentrate phase. Therefore, flotation at $\mathrm{pH}$ of 8.7 was more

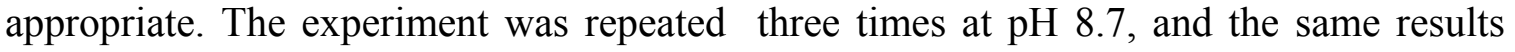
were found. 
Table 2: The results obtained from the flotation of sample $A^{* *}$

\begin{tabular}{|c|c|c|c|c|c|c|c|c|}
\hline \multirow{2}{*}{$\mathrm{PH}$} & \multirow{2}{*}{$\begin{array}{c}\text { Froth } \\
\text { Flotation }\end{array}$} & \multirow{2}{*}{$\begin{array}{c}\text { Tailling } \\
(\mathrm{g})\end{array}$} & & \multicolumn{2}{|c|}{ Recovery $(\%)$} & \multicolumn{2}{c|}{ Concentrate $(\%)$} & \multicolumn{2}{c|}{ Unfloated (\%) } \\
\cline { 4 - 9 } & & $\mathrm{Cu}^{2+}$ & $\mathrm{Co}^{2+}$ & $\mathrm{Cu}^{2+}$ & $\mathrm{Co}^{2+}$ & $\mathrm{Cu}^{2+}$ & $\mathrm{Co}^{2+}$ \\
\hline 6.0 & 8.71 & 89.43 & 59.77 & 40.23 & 13.86 & 0.68 & 0.91 & 0.10 \\
6.5 & 10.11 & 87.15 & 61.62 & 38.38 & 12.64 & 0.56 & 0.89 & 0.11 \\
7.0 & 11.22 & 85.02 & 62.85 & 37.15 & 11.85 & 0.52 & 0.89 & 0.11 \\
7.5 & 11.71 & 85.29 & 63.12 & 36.87 & 11.64 & 0.51 & 0.88 & 0.11 \\
8.0 & 12.29 & 84.75 & 65.15 & 34.75 & 10.99 & 0.48 & 0.83 & 0.12 \\
8.5 & 13.00 & 84.01 & 66.82 & 33.18 & 10.25 & 0.45 & 0.80 & 0.12 \\
10.0 & 15.63 & 81.34 & 68.98 & 31.02 & 9.28 & 0.42 & 0.77 & 0.13 \\
11.0 & 14.79 & 83.34 & 67.12 & 32.88 & 9.01 & 0.41 & 0.80 & 0.12 \\
\hline
\end{tabular}

Table 3: The results obtained from the flotation of sample $B^{* *}$

\begin{tabular}{|c|c|c|c|c|c|c|c|c|}
\hline \multirow{2}{*}{$\mathrm{PH}$} & \multirow{2}{*}{$\begin{array}{c}\text { Froth } \\
(\mathrm{g})\end{array}$} & $\begin{array}{c}\text { Tailling } \\
(\mathrm{g})\end{array}$ & & \multicolumn{2}{|c|}{ Recovery $(\%)$} & \multicolumn{2}{c|}{ Concentrate (\%) } & \multicolumn{2}{c|}{ Unfloated (\%) } \\
\cline { 5 - 9 } & & $\mathrm{Cu}^{2+}$ & $\mathrm{Co}^{2+}$ & $\mathrm{Cu}^{2+}$ & $\mathrm{Co}^{2+}$ & $\mathrm{Cu}^{2+}$ & $\mathrm{Co}^{2+}$ \\
\hline 6.0 & 9.12 & 88.06 & 59.88 & 47.01 & 13.75 & 0.65 & 0.92 & 0.09 \\
6.5 & 11.13 & 86.07 & 66.74 & 51.17 & 12.47 & 0.56 & 0.78 & 0.09 \\
7.0 & 12.00 & 85.19 & 65.82 & 56.64 & 11.82 & 0.52 & 0.81 & 0.08 \\
7.5 & 12.16 & 85.02 & 70.38 & 70.63 & 11.33 & 0.51 & 0.71 & 0.05 \\
8.0 & 12.99 & 84.19 & 75.21 & 79.18 & 10.76 & 0.46 & 0.60 & 0.04 \\
8.5 & 13.45 & 83.73 & 82.44 & 85.17 & 10.12 & 0.45 & 0.43 & 0.03 \\
10.0 & 17.00 & 80.19 & 94.15 & 90.33 & 9.76 & 0.43 & 0.15 & 0.02 \\
11.0 & 15.78 & 81.40 & 94.82 & 91.15 & 9.28 & 0.42 & 0.13 & 0.02 \\
\hline
\end{tabular}

Table 4: The results obtained from flotation of Sample $C^{* *}$

\begin{tabular}{|c|c|c|c|c|c|c|c|c|c|c|c|}
\hline & \multirow{2}{*}{$\mathrm{pH}$} & \multirow{2}{*}{$\begin{array}{c}\text { Froth } \\
\text { Flotation }\end{array}$} & \multirow{2}{*}{$\begin{array}{c}\text { Tailling } \\
\mathrm{(g})\end{array}$} & \multicolumn{3}{|c|}{ Recovery $(\%)$} & \multicolumn{3}{c|}{ Concentrate $(\%)$} & \multicolumn{3}{c|}{ Unfloated (\%) } \\
\cline { 4 - 12 } & & $\mathrm{Cu}^{2+}$ & $\mathrm{Co}^{2+}$ & $\mathrm{S}$ & $\mathrm{Cu}^{2+}$ & $\mathrm{Co}^{2+}$ & $\mathrm{S}$ & $\mathrm{Cu}^{2+}$ & $\mathrm{Co}^{2+}$ & $\mathrm{S}$ \\
\hline 6.0 & 9.73 & 88.52 & 60.18 & 47.25 & 50.15 & 11.82 & 0.51 & 25.65 & 0.91 & 0.09 & 2.10 \\
6.5 & 12.34 & 86.05 & 67.21 & 51.82 & 60.69 & 10.25 & 0.44 & 23.76 & 0.77 & 0.08 & 1.70 \\
7.0 & 15.92 & 82.95 & 65.21 & 57.82 & 71.03 & 7.82 & 0.38 & 21.54 & 0.85 & 0.08 & 1.30 \\
7.5 & 15.65 & 82.35 & 74.41 & 72.74 & 85.18 & 9.03 & 0.48 & 26.28 & 0.63 & 0.05 & 0.67 \\
8.0 & 17.13 & 81.00 & 79.72 & 82.63 & 91.32 & 8.89 & 0.50 & 26.01 & 0.51 & 0.03 & 0.40 \\
8.5 & 18.40 & 79.49 & 93.46 & 94.71 & 99.15 & 9.70 & 0.54 & 26.02 & 0.17 & 0.001 & 0.04 \\
8.6 & 18.93 & 78.07 & 96.82 & 97.02 & 100.0 & 9.14 & 0.53 & 25.50 & 0.08 & 0.006 & - \\
8.7 & 19.05 & 77.94 & 100.0 & 100.0 & 100.0 & 10.00 & 0.55 & 25.50 & - & - & - \\
8.8 & 19.92 & 77.47 & 100.0 & 100.0 & 100.0 & 9.59 & 0.53 & 24.25 & - & - & - \\
8.9 & 20.19 & 76.92 & 99.90 & 100.0 & 98.90 & 9.44 & 0.52 & 23.66 & 0.003 & - & 0.05 \\
9.0 & 20.48 & 76.61 & 99.90 & 100.0 & 98.59 & 9.32 & 0.51 & 21.50 & 0.003 & - & 0.07 \\
9.5 & 22.15 & 75.56 & 99.90 & 100.0 & 98.27 & 8.62 & 0.47 & 21.42 & 0.003 & - & 0.09 \\
10.0 & 24.09 & 74.34 & 99.89 & 99.98 & 97.68 & 7.87 & 0.43 & 19.98 & 0.003 & 0.03 & 0.11 \\
10.5 & 22.42 & 75.37 & 99.89 & 99.96 & 96.85 & 8.52 & 0.47 & 20.86 & 0.003 & 0.03 & 0.16 \\
11.0 & 22.30 & 75.71 & 99.85 & 99.90 & 96.15 & 8.44 & 0.47 & 20.82 & 0.003 & 0.03 & 0.19 \\
\hline
\end{tabular}

** Avarages calculated for data obtained from three indepented flotation experiments. 


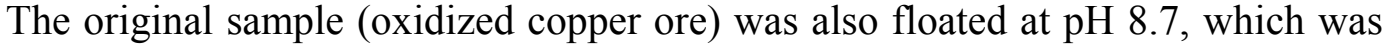
determined as optimum conditions (all other parameters were held constant). Flotation of

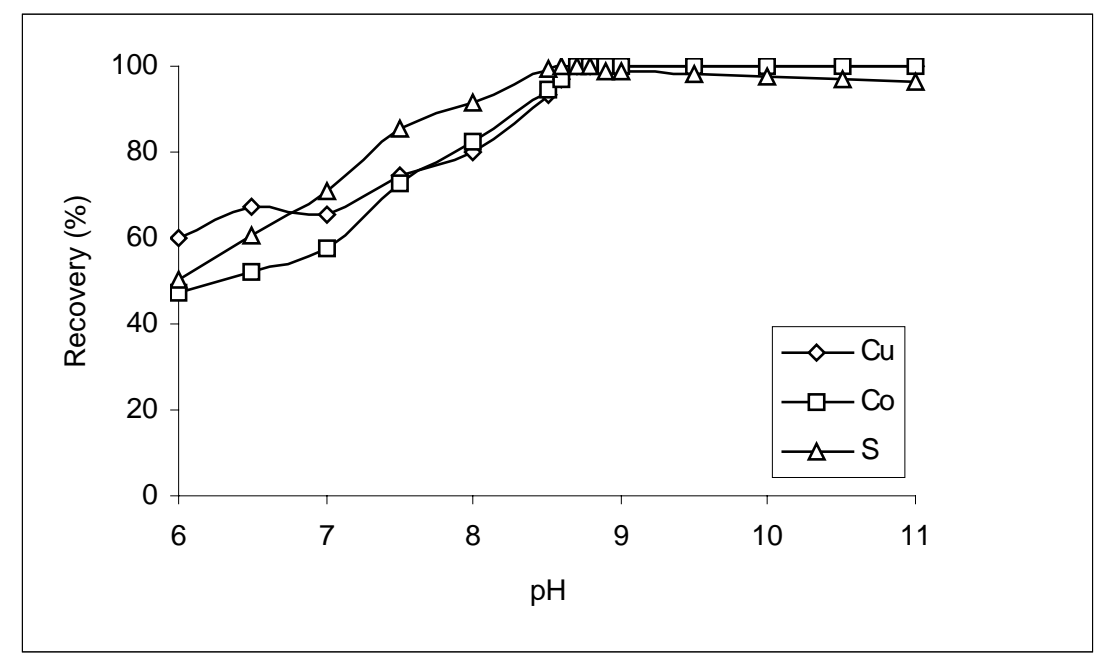

Figure 1: Alterations in flotation efficiency according to $\mathrm{pH}$ in flotation of sample $C$.

a $100.00 \mathrm{~g}$ sample resulted in $13.51 \mathrm{~g}$ reporting to the concentrate, while $85.50 \mathrm{~g}$ remained as tailing. The concentrate grade was $20.33 \%$ copper and $16.77 \%$ cobalt, enrichment was not achieved.

In the next step, flotation procedure was performed to test the effects of pulp density. The studies were carried out at $\mathrm{pH} 8.7$ (holding other parameters constant) and floating $150 \mathrm{~g}, 200 \mathrm{~g}, 250 \mathrm{f}$ and $300 \mathrm{~g}$ samples of sample C. The experimental results are given in Table 5.

Table 5: The results obtained from flotation of Sample $C^{* *}$

\begin{tabular}{|c|c|c|c|c|c|c|c|c|c|c|c|}
\hline \multirow{2}{*}{$\begin{array}{r}\text { Sam } \\
\text { ple }\end{array}$} & \multirow{2}{*}{$\begin{array}{c}\text { Froth } \\
\text { Flotation } \\
(\mathrm{g})\end{array}$} & \multirow{2}{*}{$\begin{array}{l}\text { Tailling } \\
\text { (g) }\end{array}$} & \multicolumn{3}{|c|}{ Recovery (\%) } & \multicolumn{3}{|c|}{ Concentrate $(\%)$} & \multicolumn{3}{|c|}{ Unfloated (\%) } \\
\hline & & & $\mathrm{Cu}$ & Co & $\mathrm{S}$ & $\mathrm{Cu}$ & Co & $\mathrm{S}$ & $\mathrm{Cu}$ & Co & $\mathrm{S}$ \\
\hline 150 & 29.03 & 119.75 & 100.0 & 100.0 & 100.0 & 9.89 & 0.55 & 24.98 & - & - & - \\
\hline 200 & 38.94 & 158.11 & 100.0 & 100.0 & 100.0 & 9.93 & 0.55 & 24.99 & - & - & - \\
\hline 250 & 48.10 & 199.77 & 100.0 & 100.0 & 100.0 & 9.94 & 0.54 & 25.02 & - & - & - \\
\hline 300 & 56.13 & 240.98 & 98.71 & 99.52 & 97.8 & 10.18 & 0.50 & 25.71 & 0.003 & 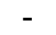 & 0.034 \\
\hline
\end{tabular}

As seen in Table 5, the results from the flotation of the samples up to $300 \mathrm{~g} / \mathrm{l}$ pulp density are fairly good. Then, coarser particles, $1-2 \mathrm{~cm}$ compared to $150 \mathrm{um}$, of the oxidized copper ore were subjected to the sulfurization process. The resulting sulfurized sample was then more easily ground to the finer size. In this series of tests, one kilogram of oxidized copper ore was subjected to the sulfurization process in mediums containing 
$30.62 \mathrm{~g} \mathrm{H}_{2} \mathrm{~S}+200.00 \mathrm{~g} \mathrm{H}_{2} \mathrm{O}\left(\mathrm{S}_{1}\right), 30.46 \mathrm{~g} \mathrm{H}_{2} \mathrm{~S}+225.00 \mathrm{~g} \mathrm{H}_{2} \mathrm{O}\left(\mathrm{S}_{2}\right)$ and $38.29 \mathrm{~g} \mathrm{H}_{2} \mathrm{~S}+$ $250.00 \mathrm{~g} \mathrm{H}_{2} \mathrm{O}\left(\mathrm{S}_{3}\right)$ mixtures, respectively. The samples obtained were ground to -100 mesh, and then flotation was performed at a $\mathrm{pH}$ of 8.7 under the same conditions as the previous flotation tests. The results are given in Table 6.

Table 6: The Results of Flotation of Ore Sulfurized without being ground**

\begin{tabular}{|c|c|c|c|c|c|c|c|c|c|c|c|}
\hline \multirow[t]{2}{*}{$\vec{\Xi}$} & \multirow{2}{*}{$\begin{array}{l}\text { Froth } \\
\text { Flotation } \\
(\mathrm{g})\end{array}$} & \multirow{2}{*}{$\begin{array}{l}\text { Tailling } \\
\text { (g) }\end{array}$} & \multicolumn{3}{|c|}{ Recovery (\%) } & \multicolumn{3}{|c|}{ Concentrate (\%) } & \multicolumn{3}{|c|}{ Unfloated (\%) } \\
\hline & & & $\mathrm{Cu}$ & $\mathrm{Co}$ & $\mathrm{S}$ & $\mathrm{Cu}$ & $\mathrm{Co}$ & $\mathrm{S}$ & $\mathrm{Cu}$ & $\mathrm{Co}$ & $\mathrm{S}$ \\
\hline $\mathrm{S}_{1}$ & 18.97 & 78.15 & 93.16 & 92.85 & 99.02 & 9.36 & 0.52 & 25.21 & 0.18 & 0.014 & 0.047 \\
\hline $\mathrm{S}_{2}$ & 19.23 & 77.96 & 96.95 & 97.81 & 99.97 & 9.48 & 0.52 & 25.12 & 0.08 & 0.004 & 0.001 \\
\hline $\mathrm{S}_{3}$ & 19.77 & 77.25 & 99.52 & 99.99 & 99.98 & 9.66 & 0.53 & 24.87 & 0.013 & - & - \\
\hline
\end{tabular}

As seen in Table 6, for the sulfurization of coarse ore, more $\mathrm{H}_{2} \mathrm{~S}$ was needed than for finer ore particles. So, in order to sulfurize one $\mathrm{kg}$ of ore, the medium, containing $38,30 \mathrm{~g} \mathrm{H}_{2} \mathrm{~S}+250.00 \mathrm{~g} \mathrm{H}_{2} \mathrm{O}$ was used. The ore sulfurized this way ground more easily with respect to the original ore. In addition to that, the flotation efficiency is fairly higher.

\section{Particle Size}

When the sulfurized sample was analyzed by using flotation process, the following results were found.

+120 mesh $=25.91 \% \quad+200$ mesh $=38.82 \%$

+140 mesh $=32.51 \% \quad-200$ mesh $=4.80 \%$

Flotation studies were done using this particle size distribution.

\section{CONCLUSIONS}

The findings of this study are as follows:

1. Enrichment can not be achieved with the flotation of original ore.

2. The recovery of copper and cobalt is not economical using hydrometallurgical methods.

3. For enrichment with flotation, it was understood that a new surface is required.

4. It was determined that the efficiency increased with the flotation of the sample obtained from sulfurization of oxidized copper ore, sized to -100 mesh, with the appropriate amount of $\mathrm{H}_{2} \mathrm{~S}$. e.g. for sulfurization of one $\mathrm{kg}$ of sieved ore, $30.70 \mathrm{~g}$ $\mathrm{H}_{2} \mathrm{~S}+200.00 \mathrm{~g} \mathrm{H}_{2} \mathrm{O}$ is enough; while for coarser ore samples, 38.30 $\mathrm{g} \mathrm{H}_{2} \mathrm{~S}+$ $250.00 \mathrm{~g} \mathrm{H}_{2} \mathrm{O}$ should be used.

5. When the flotation of copper, cobalt and sulfur is performed at $\mathrm{pH} 8.7$, maximum efficiency was obtained (approximately $100 \%$ for three elements).

6. Increase in the efficiency in the flotation of sulfurized samples is not only limited to the oxidized copper ore; flotation of different copper ores has also been 
achieved with high efficiency. The amount of $\mathrm{H}_{2} \mathrm{~S}$ used according to the composition of copper ore must be determined experimentally.

7. We didn't need to use selective flotation following collective flotation because we developed a new economic method to recover copper and cobalt from the concentrated phase after using collective flotation.

8. Some alterations occurred in the composition of the ore during the sulfurization process. These included degradation in the spinal structure, reduction of ions at some high state orders and differences in crystalline structure. As a result, sulfide compounds were formed, and degrees of freedom were increased after the treatments. Sulfide compounds formed in this way will more easily adsorb collector and attach to the foam more readily, and will float. For these reasons, the sulfurization process was applied before flotation.

\section{REFERENCES}

1 Acherman P. K., Harris G. H., Klimpel R.R., Aplan F. F., Int. J. Miner. Process (Elsevier), 58, 1 (2000).

2 Aydın F., Ph.D Thesis, University of Dicle, Turkey (2002).

3 Aydın I., Ph.D Thesis, University of Dicle, Turkey (2001) .

4 Basak S., Charewicz W. A., I. Chem. Tech. Biotech., 36, 74 (1986) .

5 Cöcen İPh.D Thesis, University of Dokuz Eylül Turkey (1986).

6 Fornari P., Abbruzzese C., Hydrometallurgy, 52(3), 209 (1999).

7 Gaballah I., Djona M., Metallurgical and Materials Transactions B ,25B, 481(1994).

8 Ghodsi M., Detournay J., Schrabiltgen J-M., Naessens G., J. Chem. Tech. Biotechnol. 37, 133 (1987).

9 Kongolo K., et all., Minerals Engineering ,16, 1023-1026 (2003).

10 Mainza N., Simukanga S., Witika L.K., Minerals Engineering ,12(9), 1033 (1999).

11 Maurice D., Hawk J. A., Hydrometallurgy, 49 (1-2), 103 (1998).

12 Ngoc N.V., Shamsuddin M., Prasad P. M., Hydrometallurgy, 21, 359 (1989).

13 Özer A., MSc Thesis, University of Firat, Turkey (1991)

14 Özönder Ö, MSc Thesis University of METU, Turkey (1994).

15 Shen W.Z., D. Fornasiero, J.Ralston, Int.J. Miner. Process, 63, 17 (2001).

16 Shu J., Lakshmanan V.I., Convey J., Canadian Metallurgical Quarterly, 38(4), 215 (1999).

17 Tadeusz Stefanowicz, Malgorzata Osinska, Stefania Napieralska Zagozda, Hydrometallurgy, 47(1), 69 (1997).

18 Thakur N.V., Mishara S.L., Hydrometalurgy, 48 (3), 227 (1998). 